\title{
Role of Integrated Use of Organic Manures and Inorganic Fertilizers on Mulberry and its Impact on Cocoon Parameters of Silkworm (Bombyx mori L.)
}

\author{
S.N. Sudhakara*, T.K. Narayanaswamy and K.C. Narayanaswamy \\ Department of Sericulture, University of Agricultural Sciences, \\ Bangalore-560 065, Karnataka, India \\ *Corresponding author
}

\section{A B S T R A C T}

\section{Keywords}

Feeding schedules,

Mulberry, Silkworms,

Bio fertilizers,

Organic and inorganic

fertilizers, Cocoon

parameters.

Article Info

Accepted:

28 September 2017

Available Online:

10 November 2017
An research experiment was carried out at Main Research Station, UAS, Hebbal, Bangalore to study the role of organic and inorganic fertilizers applied to mulberry on the cocoon parameters of silkworm. The cocoon weight (1.40 $\mathrm{g}$ and $1.50 \mathrm{~g})$, shell weight $(0.299 \mathrm{~g}$ and $0.325 \mathrm{~g})$, shell ratio ( 21.44 and $21.70 \%$ ), silk productivity (4.46 and $5.23 \mathrm{cg} /$ day) and cocoon yield (48.19 and $53.96 \mathrm{~kg} / 100$ DFLs) were significant maximum when chawki worms fed with $S_{36}$ and late age worm with M5 leaves and worms fed with leaves raised through application of recommended 20 tones compost + 300: 120: $120 \mathrm{~kg} \mathrm{~N}, \mathrm{P}$ and K/ha/year through fertilizer.

\section{Introduction}

Mulberry being the perennial crop requires a continuous and adequate supply of nutrients to get sustained yield. Due to continuous cultivation of mulberry, the soil moisture gets depleted. The yield of mulberry depends on the soil type, available plant nutrients in the soil and other agro-climatic factors. However, native soil fertility alone cannot be relied upon for quality and quantity of mulberry leaf productivity unless the soil is replenished with external nutrient sources through fertilizers. Dasgupta (1961) stated that cocoon characters were dependent on the nutritive value of leaves. Hence, package of manurial schedule for mulberry and feeding schedules for silkworm plays a vital role for obtaining a good cocoon crop.

\section{Materials and Methods}

The experiment was carried out to study the role of organic manures and inorganic fertilizers, which are applied to mulberry on pre-cocoon parameters of silkworm. Silkworm feeding trails of four feeding schedules with two different mulberry varieties $\left(\mathrm{S}_{36}\right.$ and $\left.\mathrm{M}_{5}\right)$ with thirteen treatment combination along with three replication were followed. One hundred worms were maintained in each replication of every 
treatment. Feeding schedules (FS) viz., FS $_{1}$ (chawki worms fed with $\mathrm{S}_{36}$ leaf + late age worms fed with $\mathrm{S}_{36}$ leaf), $\mathrm{FS}_{2}$ (chawki worms fed with $\mathrm{S}_{36}$ leaf + late age worms fed with $\mathrm{M}_{5}$ leaf), $\mathrm{FS}_{3}$ (chawki worms fed with $\mathrm{M}_{5}$ leaf + late age worms fed with $\mathrm{S}_{36}$ leaf) and $\mathrm{FS}_{4}$ (chawki worms fed with $\mathrm{M}_{5}$ leaf + late age worms fed with $\mathrm{M}_{5}$ leaf) respectively.

The leaves of two different mulberry varieties grown with different treatments fed to bivoltine silkworm breed, $\mathrm{CSR}_{2}$. The packages of practices for silkworm rearing were carried out as per the recommendations (Dandin et al., 2014). The observations on cocoon weight, shell weight, shell ratio, silk productivity and cocoon yield were recorded treatment wise, feeding schedule wise. The data were analyzed statistically by adopting two way factorial RCBD as outlined by Cochron and Cox (2000).

\section{Treatment details}

T1: $100 \%$ recommended $\mathrm{N}$ through Compost

T2: $50 \%$ recommended $\mathrm{N}$ through Compost $+50 \%$ recommended $\mathrm{N}$ and remaining $\mathrm{P}, \mathrm{K}$ through fertilizer

T3: $100 \%$ recommended $\mathrm{N}$ through Green manure (Glyricidia maculata)

T4: $50 \%$ recommended $\mathrm{N}$ through Green manure $+50 \%$ recommended $\mathrm{N}$ and remaining $\mathrm{P}, \mathrm{K}$ through Fertilizer

T5: $100 \%$ recommended $\mathrm{N}$ through Castor oil cake

T6: $50 \%$ recommended $\mathrm{N}$ through Castor oil cake $+50 \%$ recommended $\mathrm{N}$ and remaining $\mathrm{P}, \mathrm{K}$ through Fertilizer

T7: $35 \%$ recommended $\mathrm{N}$ through Compost $+30 \%$ recommended $\mathrm{N}$ through Castor oil cake $+35 \%$ recommended $\mathrm{N}$ through Green manure

T8: $100 \%$ recommended $\mathrm{N}$ through Vermicompost

T9: $50 \%$ recommended $\mathrm{N}$ through Vermicompost $+50 \%$ recommended $\mathrm{N}$ and remaining $\mathrm{P}, \mathrm{K}$ through Fertilizer

T10: Bio-fertilizers $10 \mathrm{~kg}$ each of Azospirillum + Aspergillus awamori/ha/yr + $25 \%$ recommended $\mathrm{N}$ through each of Compost, Green manure, Castor oil cake and vermicompost

T11: Bio-fertilizers $10 \mathrm{~kg}$ each of Azospirillum + Aspergillus awamori/ha/yr + $20 \%$ recommended $\mathrm{N}$ through each of Compost, Green manure, Castor oil cake, vermicompost and fertilizer + remaining $\mathrm{P}, \mathrm{K}$ through fertilizer

T12 (control): Recommended 20 tones compost + 300: 120: $120 \mathrm{~kg} \mathrm{~N}, \mathrm{P}$ and K / ha / year through fertilizer

T13 (control): Only fertilizer 300: 120: 120 $\mathrm{kg}$ of $\mathrm{N}, \mathrm{P}$ and $\mathrm{K} / \mathrm{ha} /$ year

\section{Results and Discussion}

The data on the results of the present study are presented in Table 1 and 2 .

Among different treatments, $\mathrm{T}_{12}$ Recommended 20 tones compost +300 : 120: $120 \mathrm{~kg} \mathrm{~N}, \mathrm{P}$ and $\mathrm{K} / \mathrm{ha} /$ year through fertilizer exhibited higher cocoon weight $(1.50 \mathrm{~g})$ followed by $\mathrm{T}_{11}$ Bio-fertilizers $10 \mathrm{~kg}$ each of Azospirillum + Aspergillus awamori/ha/yr $+20 \%$ recommended $\mathrm{N}$ through each of Compost, Green manure, Castor oil cake, vermicompost and fertilizer + remaining $\mathrm{P}, \mathrm{K}$ through fertilizer (1.44 g). Whereas, $\mathrm{T}_{1} 100 \%$ recommended $\mathrm{N}$ through 
Compost (1.3.5 g), $\mathrm{T}_{2} 50 \%$ recommended $\mathrm{N}$ through Compost $+50 \%$ recommended $\mathrm{N}$ and remaining $\mathrm{P}, \mathrm{K}$ through fertilizer $(1.34 \mathrm{~g})$, $\mathrm{T}_{3} \quad 100 \%$ recommended $\mathrm{N}$ through Green manure (Glyricidia maculata) (1.34 g), $\mathrm{T}_{7} 35$ $\%$ recommended $\mathrm{N}$ through Compost $+30 \%$ recommended $\mathrm{N}$ through Castor oil cake +35 $\%$ recommended $\mathrm{N}$ through Green manure $(1.37 \mathrm{~g})$ and $\mathrm{T}_{8} 100 \%$ recommended $\mathrm{N}$ through Vermicompost $(1.33 \mathrm{~g})$ were on par with each other. The shell weight was influenced by feeding of leaves obtained through application of different sources of organic manures and inorganic fertilizers, which differed significantly in all the treatments.

Among the treatments, highest shell weight was recorded in $T_{12}(0.325 \mathrm{~g})$ followed by $\mathrm{T}_{11}$ $(0.312 \mathrm{~g})$ and $\mathrm{T}_{10}$ Bio-fertilizers $10 \mathrm{~kg}$ each of Azospirillum + Aspergillus awamori $/ \mathrm{ha} / \mathrm{yr}+$ 25\% recommended $\mathrm{N}$ through each of Compost, Green manure, Castor oil cake and vermicompost $(0.308 \mathrm{~g})$. Significant influence was registered in shell ratio by $\mathrm{T}_{10}(21.87 \%)$ followed by $\mathrm{T}_{12}(21.7 \%)$ and $\mathrm{T}_{11}(21.51 \%)$.

The cocoon weight, shell weight and shell ratio were increased significantly in $T_{12}$ as well as $\mathrm{T}_{11}$. Similar results have been obtained by Umesh (1999), who reported that the use of biofertilizers (Azotobactor) with 50 per cent recommended ' $\mathrm{N}$ ' has improved the quality of cocoons and silk parameters.

Silk productivity was found to be influenced by the application of different sources of organic manures and inorganic fertilizers. Among different treatment combinations $\mathrm{T}_{12}$ (5.23 cg/day) expressed maximum silk productivity compared to $T_{13}$. Only fertilizer 300: 120: $120 \mathrm{~kg}$ of N, P and $\mathrm{K} /$ ha / year ( $3.15 \mathrm{cg} /$ day $)$. Whereas, $\mathrm{T}_{1}(3.78 \mathrm{cg} /$ day $)$ and $\mathrm{T}_{2}(3.80 \mathrm{cg} / \mathrm{day})$ were on par with each other with respect to silk productivity. These results are agreement with those of Shankar and
Shivashankar (1994); Rajanna et al., (2000a), who observed that combined application of sericulture by-products along with fertilizers registered highest silk productivity. Maximum cocoon yield was obtained in $\mathrm{T}_{12}(53.96 \mathrm{~kg})$ followed by $\mathrm{T}_{11}(51.76 \mathrm{~kg})$. But, other treatments such as $\mathrm{T}_{1}(43.52 \mathrm{~kg}), \mathrm{T}_{5} 100 \%$ recommended $\mathrm{N}$ through Castor oil cake $(43.95 \mathrm{~kg})$ and $\mathrm{T}_{7}(43.91 \mathrm{~kg})$ were on par with each other with respect to cocoon yield.

Increase in these parameters were influenced by different sources of organic manures and inorganic fertilizers which were applied to mulberry might have increased the crude protein content in leaves which in turn influenced the silk productivity and cocoon yield.

The feeding schedule $\left(\mathrm{FS}_{2}\right)$ ranked first for majority of the pre-cocoon parameters viz., single cocoon weight $(1.40 \mathrm{~g})$, single shell weight $(0.299 \mathrm{~g})$, shell ratio $(21.44 \%)$, silk productivity (4.46 cg/day) and cocoon yield $(48.19 \mathrm{~kg} / 100 \mathrm{DFLs})$. Feeding of chawki worms with $\mathrm{S}_{36}$ leaf and late age worms with $\mathrm{M}_{5}$ mulberry leaf resulted in desirable precocoon parameters. This might be due to suitability of $\mathrm{S}_{36}$ leaf to chawki and $\mathrm{M}_{5}$ leaf to late age worms. Scanning of available literature revealed that, there is no such on these lines. Hence, comparisons are not made.

However, Basavanna et al., (1974) reported that variety, spacing and nitrogen levels have influenced chemical composition of mulberry leaves. In view of this it may be opined that, nitrogen supplied through different sources of organic manures and inorganic fertilizer might have influenced the cocoon parameters.

Similarly, Venugopal Pillai et al., (1987) reported that, application of $900 \mathrm{~kg}$ of N/ha/yr improved the feeding quality of the leaves and also to great extent increased the growth rate and cocoon yield. 
Table.1 Cocoon weight $(\mathrm{g})$, shell weight $(\mathrm{g})$ and shell ratio $(\%)$ as influenced by feeding of leaf obtained by application of $\mathrm{N}$ through different sources of organic manures and inorganic fertilizers

\begin{tabular}{|c|c|c|c|c|c|c|c|c|c|c|c|c|c|c|c|}
\hline \multirow{4}{*}{$\begin{array}{c}\text { Treatments } \\
\text { (T) }\end{array}$} & \multicolumn{12}{|c|}{ Cocoon weight $(\mathrm{g})$, Shell weight $(\mathrm{g})$ and Shell ratio (\%) } & \multirow{3}{*}{\multicolumn{3}{|c|}{$\begin{array}{c}\text { Mean } \\
(\mathbf{T})\end{array}$}} \\
\hline & \multicolumn{12}{|c|}{ Feeding Schedules (FS) } & & & \\
\hline & \multicolumn{3}{|c|}{$\mathbf{F S}_{1}$} & \multicolumn{3}{|c|}{$\mathbf{F S}_{2}$} & \multicolumn{3}{|c|}{$\mathbf{F S}_{\mathbf{3}}$} & \multicolumn{3}{|c|}{$\mathbf{F S}_{\mathbf{4}}$} & & & \\
\hline & $\mathrm{CW}$ & SW & SR & CW & SW & SR & $\mathrm{CW}$ & SW & SR & $\mathrm{CW}$ & SW & SR & CW & SW & SR \\
\hline $\mathbf{T}_{1}$ & 1.35 & 0.273 & 20.36 & 1.37 & 0.283 & 20.79 & 1.33 & 0.263 & 19.91 & 1.31 & 0.260 & 19.84 & 1.35 & 0.270 & 20.23 \\
\hline$T_{2}$ & 1.35 & 0.280 & 20.73 & 1.37 & 0.283 & 20.72 & 1.29 & 0.260 & 20.15 & 1.34 & 0.270 & 20.14 & 1.34 & 0.273 & 20.43 \\
\hline$T_{3}$ & 1.37 & 0.280 & 20.35 & 1.35 & 0.293 & 21.60 & 1.29 & 0.263 & 19.92 & 1.35 & 0.273 & 20.46 & 1.34 & 0.277 & 20.58 \\
\hline $\mathbf{T}_{4}$ & 1.37 & 0.283 & 20.79 & 1.39 & 0.293 & 21.42 & 1.33 & 0.263 & 19.92 & 1.33 & 0.263 & 19.91 & 1.36 & 0.275 & 20.51 \\
\hline $\mathbf{T}_{5}$ & 1.33 & 0.273 & 20.67 & 1.32 & 0.273 & 20.82 & 1.29 & 0.260 & 20.15 & 1.29 & 0.260 & 20.15 & 1.30 & 0.266 & 20.42 \\
\hline$T_{6}$ & 1.36 & 0.280 & 20.58 & 1.41 & 0.310 & 21.98 & 1.35 & 0.273 & 20.36 & 1.35 & 0.293 & 21.21 & 1.37 & 0.289 & 21.03 \\
\hline $\mathbf{T}_{7}$ & 1.31 & 0.263 & 20.22 & 1.38 & 0.283 & 20.58 & 1.31 & 0.260 & 19.85 & 1.33 & 0.263 & 19.91 & 1.33 & 0.267 & 20.14 \\
\hline $\mathbf{T}_{8}$ & 1.33 & 0.270 & 20.29 & 1.39 & 0.293 & 21.21 & 1.32 & 0.260 & 20.15 & 1.31 & 0.260 & 19.85 & 1.33 & 0.270 & 20.37 \\
\hline $\mathbf{T}_{9}$ & 1.41 & 0.303 & 21.29 & 1.42 & 0.320 & 22.53 & 1.37 & 0.283 & 20.79 & 1.35 & 0.273 & 20.37 & 1.38 & 0.295 & 21.24 \\
\hline$T_{10}$ & 1.41 & 0.320 & 22.61 & 1.43 & 0.320 & 22.37 & 1.41 & 0.300 & 21.27 & 1.39 & 0.293 & 21.22 & 1.41 & 0.308 & 21.87 \\
\hline $\mathbf{T}_{11}$ & 1.43 & 0.320 & 22.10 & 1.49 & 0.323 & 21.59 & 1.42 & 0.303 & 21.30 & 1.45 & 0.303 & 21.05 & 1.44 & 0.312 & 21.51 \\
\hline $\mathbf{T}_{12}$ & 1.48 & 0.323 & 21.96 & 1.55 & 0.343 & 21.92 & 1.47 & 0.313 & 21.42 & 1.51 & 0.323 & 21.52 & 1.50 & 0.325 & 21.70 \\
\hline $\mathbf{T}_{13}$ & 1.29 & 0.263 & 20.46 & 1.33 & 0.273 & 21.26 & 1.29 & 0.243 & 18.99 & 1.26 & 0.256 & 19.36 & 1.29 & 0.256 & 20.02 \\
\hline Mean (S) & 1.37 & 0.287 & 20.95 & 1.40 & 0.299 & 21.44 & 1.34 & 0.272 & 20.32 & 1.35 & 0.275 & 20.38 & & & \\
\hline
\end{tabular}

\begin{tabular}{|c|c|c|c|c|c|c|c|c|c|}
\hline & \multicolumn{3}{|c|}{ Feeding Schedules (FS) } & \multicolumn{3}{|c|}{ Treatments $(\mathrm{T})$} & \multicolumn{3}{|c|}{ Interactions $(\mathrm{FS} \times \mathrm{T})$} \\
\hline & CW & SW & SR & CW & SW & SR & $\mathrm{CW}$ & SW & SR \\
\hline F-Test & $*$ & $*$ & $*$ & $*$ & $*$ & $*$ & $*$ & $*$ & $*$ \\
\hline SEm \pm & 0.0032 & 0.0008 & 0.058 & 0.0057 & 0.0015 & 0.105 & 0.011 & 0.0030 & 0.210 \\
\hline CD at $5 \%$ & 0.0088 & 0.0023 & 0.016 & 0.0159 & 0.0041 & 0.292 & 0.031 & 0.0082 & 0.584 \\
\hline
\end{tabular}

$\mathrm{CW}=$ Cocoon weight, $\mathrm{SW}=$ Shell weight, $\mathrm{SR}=$ Shell ratio

Note: $\mathrm{FS}_{1}$ : Chawki worms fed with $\mathrm{S}_{36}$ leaf + Late age worms fed with $\mathrm{S}_{36}$ leaf

$\mathrm{FS}_{2}$ : Chawki worms fed with $\mathrm{S}_{36}$ leaf + Late age worms fed with $\mathrm{M}_{5}$ leaf

$\mathrm{FS}_{3}$ : Chawki worms fed with $\mathrm{M}_{5}$ leaf + Late age worms fed with $\mathrm{S}_{36}$ leaf

$\mathrm{FS}_{4}$ : Chawki worms fed with $\mathrm{M}_{5}$ leaf + Late age worms fed with $\mathrm{M}_{5}$ leaf 
Table.2 Silk productivity (cg/day) and cocoon yield (kg/100 DFL's) as influenced by feeding of leaf obtained by application of N through different sources of organic manures and inorganic fertilizers

\begin{tabular}{|c|c|c|c|c|c|c|c|c|c|c|}
\hline \multirow{4}{*}{$\begin{array}{c}\text { Treatments } \\
\text { (T) }\end{array}$} & \multicolumn{8}{|c|}{ Silk productivity (cg/day) and Cocoon yield (kg/100 DFL's) } & \multirow{3}{*}{\multicolumn{2}{|c|}{$\begin{array}{c}\text { Mean } \\
(\mathbf{T})\end{array}$}} \\
\hline & \multicolumn{8}{|c|}{ Feeding Schedules (FS) } & & \\
\hline & \multicolumn{2}{|c|}{$\mathbf{F S}_{1}$} & \multicolumn{2}{|c|}{$\mathbf{F S}_{\mathbf{2}}$} & \multicolumn{2}{|c|}{$\mathbf{F S}_{\mathbf{3}}$} & \multicolumn{2}{|c|}{$\mathbf{F S}_{4}$} & & \\
\hline & SP & $\mathrm{CY}$ & SP & $\mathrm{CY}$ & SP & $\mathrm{CY}$ & SP & $\mathrm{CY}$ & SP & CY \\
\hline $\mathbf{T}_{1}$ & 3.83 & 43.19 & 3.98 & 45.30 & 3.69 & 44.15 & 3.61 & 42.44 & 3.78 & 43.52 \\
\hline $\mathbf{T}_{2}$ & 3.88 & 46.35 & 3.96 & 48.13 & 3.63 & 42.82 & 3.75 & 44.50 & 3.80 & 45.45 \\
\hline$T_{3}$ & 3.13 & 45.37 & 4.20 & 45.45 & 3.74 & 44.16 & 3.62 & 44.82 & 3.87 & 44.93 \\
\hline $\mathbf{T}_{4}$ & 4.31 & 46.11 & 4.13 & 47.75 & 3.70 & 45.22 & 3.71 & 46.29 & 3.96 & 46.34 \\
\hline $\mathbf{T}_{5}$ & 3.82 & 44.22 & 3.83 & 44.41 & 3.62 & 43.85 & 3.63 & 43.34 & 3.72 & 43.95 \\
\hline $\mathbf{T}_{6}$ & 3.98 & 47.59 & 4.97 & 47.95 & 3.87 & 46.98 & 4.52 & 50.60 & 4.33 & 48.28 \\
\hline $\mathbf{T}_{7}$ & 3.69 & 43.22 & 3.99 & 44.78 & 3.64 & 42.44 & 3.70 & 45.22 & 3.75 & 43.91 \\
\hline $\mathbf{T}_{8}$ & 3.76 & 44.77 & 4.12 & 45.87 & 3.63 & 44.88 & 3.62 & 43.41 & 3.78 & 44.75 \\
\hline $\mathbf{T}_{9}$ & 4.90 & 48.41 & 5.20 & 50.64 & 4.59 & 45.48 & 4.43 & 45.90 & 4.78 & 47.61 \\
\hline$T_{10}$ & 5.14 & 50.46 & 5.21 & 51.00 & 4.83 & 50.19 & 4.75 & 49.48 & 4.98 & 50.28 \\
\hline $\mathbf{T}_{11}$ & 5.24 & 51.45 & 5.34 & 55.12 & 4.91 & 47.71 & 4.91 & 52.77 & 5.10 & 51.76 \\
\hline $\mathbf{T}_{12}$ & 5.24 & 53.77 & 5.74 & 58.38 & 5.07 & 51.16 & 4.89 & 52.55 & 5.23 & 53.96 \\
\hline $\mathbf{T}_{13}$ & 3.23 & 41.01 & 3.39 & 42.73 & 2.99 & 40.76 & 2.99 & 39.97 & 3.15 & 41.11 \\
\hline Mean (S) & 4.23 & 46.61 & 4.46 & 48.19 & 3.99 & 44.37 & 4.01 & 46.26 & & \\
\hline
\end{tabular}

\begin{tabular}{|l|c|c|c|c|c|c|}
\hline & \multicolumn{2}{|c|}{ Feeding Schedules (FS) } & \multicolumn{2}{c|}{ Treatments (T) } & \multicolumn{2}{c|}{ Interactions (FS $\times$ T) } \\
\hline & SP & CY & SP & CY & SP & CY \\
\hline F-Test & $*$ & $*$ & $*$ & $*$ & $*$ & $*$ \\
\hline SEm \pm & 0.027 & 0.096 & 0.049 & 0.173 & 0.098 & 0.346 \\
\hline CD at 5 \% & 0.075 & 0.266 & 0.136 & 0.480 & 0.272 & 0.960 \\
\hline
\end{tabular}

$\mathrm{SP}=$ Silk productivity

$\mathrm{CY}=$ Cocoon yield

Note: $\mathrm{FS}_{1}$ : Chawki worms fed with $\mathrm{S}_{36}$ leaf + Late age worms fed with $\mathrm{S}_{36}$ leaf

$\mathrm{FS}_{2}$ : Chawki worms fed with $\mathrm{S}_{36}$ leaf + Late age worms fed with $\mathrm{M}_{5}$ leaf

$\mathrm{FS}_{3}$ : Chawki worms fed with $\mathrm{M}_{5}$ leaf + Late age worms fed with $\mathrm{S}_{36}$ leaf

$\mathrm{FS}_{4}$ : Chawki worms fed with $\mathrm{M}_{5}$ leaf + Late age worms fed with $\mathrm{M}_{5}$ leaf 
Narayanan et al., (1966) reported that, application of nitrogen to mulberry significantly influenced the cocoon production, since it has profound influence on larval, cocoon and shell weights, shell percentage and cocoon yield as nitrogen promotes protein content in mulberry leaf. However, interaction effect in $\mathrm{FS}_{2} \mathrm{~T}_{12}$ was superior in respect of cocoon weight $(1.55 \mathrm{~g})$, shell weight $(0.343 \mathrm{~g})$, silk productivity $(5.74$ $\mathrm{cg} /$ day) and cocoon yield $(58.38 \mathrm{~kg} / 100$ DFLs).

\section{Acknowledgement}

The authors express their heartfelt thanks to Department of Science and Technology (DST) New Delhi for providing financial assistance for conducting the research work.

\section{References}

Basavanna, H. M., Srinivasan, E. B. and Kodanandaram, M. M., 1974. Studies on the quality of mulberry leaves with different varieties and fertilizers. Ann. Rep., CSR\&TI, Mysore, pp. 114-116.

Cochran and Cox, 2000. Experimental Design Procedures for the Behavioural Sciences, Cole Publishing Company, pp. 319-380.

Dandin, S. B., Jayant Jayaswal and Giridhar, K., 2014. Handbook of Sericulture Technologies, CSB, Bangalore, pp.346373.

Dasgupta, K., 1961. Feeding mulberry to silkworm: a comparitive analytical study on the effect of feeding with different types of mulberry leaves obtained by different methods of cultivation on silkworm (Bombyx mori L.), Indian silk, 1: 4.

Narayanan, E. S., Kasiviswanathan, K. and Iyengar, M. N. S., 1966. Effect of varietal feeding, irrigation levels and nitrogen fertilization on the larval development and cocoon characters of Bombyx mori L. Indian J. Seric., 5: 1317.

Rajanna, B. H., Chinnaswamy, K. P., Govindan, R., Sannappa, B. and Sundar Raj, S., 2000a. Effect of sericulture byproducts and other organic manures on leaf yield and elemental composition of mulberry. Bull. Ind. Acad. Seric., 4: 7074.

Shankar, M. A. and Shivashankar, K., 1994. Effect of sources of nitrogen on filament length, cocoon yield and silk quality. Mysore J. Agri. Sci., 28: 157164.

Umesh, M. P., 1999. Response of RFS-175 and $\mathrm{M}_{5}$ mulberry varieties to Azotobactor inoculation in relation to growth, yield of mulberry and cocoon production under dry land alfisols. M.Sc. (Seri.) Thesis, UAS, Bangalore. P. 98.

Venugopal Pillai, S., Krishnaswami, S. and Kasiviswanathan, K., 1987. Growth studies in silkworm, Bombyx mori L. under tropical conditions. Influence of agronomical methods of mulberry on the growth, cocoon and fecundity of silkworm. Indian J. Seric., 26: 32-45.

\section{How to cite this article:}

Sudhakara, S.N., T.K. Narayanaswamy and Narayanaswamy, K.C. 2017. Role of Integrated Use of Organic Manures and Inorganic Fertilizers on Mulberry and its Impact on Cocoon Parameters of Silkworm (Bombyx mori L.). Int.J.Curr.Microbiol.App.Sci. 6(11): 3922-3927. doi: https://doi.org/10.20546/ijcmas.2017.611.458 